\title{
Rise of Prostanoids in Rat Small Intestinal Mucosa following Intestinal Protein Hypersensitivity
}

\author{
D. BRANSKI, M. ERAN, P. SHARON, E. GROSS-KIESELSTEIN, J. WEIDENFELD, AND \\ S. FREIER \\ Bikur Cholim Hospital [D.B., P.S., E.G-K., J.W.J, Shaare Zedek Hospital [M.E., S.F.], Jerusalem, Israel
}

\begin{abstract}
The purpose of the present study was to establish whether there is an elevated prostaglandin concentration in the intestinal mucosa in rats suffering from an immediate type hypersensitivity reaction. Rats of the Hooded-Lister strain were sensitized and challenged with ovalbumin. Control rats were given adjuvant only. Prostanoid content of scraped mucosa was determined by radioimmunoassay. It was found that the prostaglandin $E_{2}$ content in the sensitized intestine was significantly elevated as compared to the controls. There was no significant rise of 6-keto prostaglandin $F_{\alpha}$ or thromboxane $E_{2}$ in the sensitized rats. These results show that prostaglandin $B_{2}$ participates in intestinal immediate type responses and may explain some of the clinical manifestations of food protein allergy. (Pediatr Res 21: 414-416, 1987)
\end{abstract}

\section{Abbreviations}

PG, prostaglandin

$\mathrm{TXB}_{2}$, thromboxane $\mathrm{B}_{2}$

PCA, passive cutaneous anaphylaxis

The gastrointestinal manifestations of food hypersensitivity are similar to the effects elicited by administration of exogenous prostanoids (1). The possibility exists therefore, that prostanoids are involved in the symptomatology of immediate type hypersensitivity reactions in the intestine. In order to test this hypothesis, we used rats sensitized with ovalbumin, and subsequently challenged with this protein. We have previously shown that in these sensitized animals an immediate allergic type reaction in the small intestine can be developed upon challenge with ovalbumin (2). Herein we were able to show that the prostanoid content of such a challenged mucosa is raised.

\section{MATERIALS AND METHODS}

Sensitization and challenge. Rats of Hooded-Lister strain were used. Their weight ranged between 150 and $180 \mathrm{~g}$. Nineteen rats were sensitized by an intraperitoneal injection of ovalbumin 250 $\mu \mathrm{g} / 0.5 \mathrm{ml}$ with adjuvant consisting of killed Bordetella pertussis $\left(1.6 \times 10^{3} / 0.5 \mathrm{ml}\right)$. On the 14th day a booster injection of ovalbumin $(2.5 \mu \mathrm{g} / 0.5 \mathrm{ml})$ was given intraperitoneally. In our experience this method of sensitization has always resulted in a

Received September 8, 1986; accepted December 2, 1986.

Address for correspondence David Branski, M.D., Chief, Division of Pediatric Gastroenterology and Nutrition, Department of Pediatrics, Bikur Cholin Hospital, POB 492, Jcrusalem 91004, Israel.

Supported by a grant in memory of Dr. Mauricio Schapira and by a grant from Smith, Klein and French Inc. positive passive cutaneous anaphylactic reaction (2). The challenge procedure was based on that described by Byars and Ferraresi (3). On the 19th day the rats were challenged with 25 mg ovalbumin intragastrically (Sigma Chemical Co.) after an overnight fast. Forty-five min after the ovalbumin challenge, the rats were anesthetized with ether and then sacrificed. The first 5 $\mathrm{cm}$ of intestine immediately distal to the pylorus were removed, rinsed with ice-cold saline, and the mucosa was scraped and stored at $70^{\circ} \mathrm{C}$ for PGs determination. The control group consisted of 17 rats which were injected only with the adjuvant 19 days before challenge. They were challenged as the sensitized group.

Prostanoid determination. The tissue was sonicated in $1.0 \mathrm{ml}$ of ice-cold $50 \mathrm{mM}$ Tris-HCl buffer, $\mathrm{pH} 7.0$, containing $0.02 \mathrm{M}$ EDTA. The homogenate was centrifuged and the supernatant was extracted twice with $2 \mathrm{vol}$ of ether. The aqueous phases were assayed for their PG content.

$\mathrm{PGE}_{2}$ was determined by radioimmunoassay as described by Bauminger et al. (4). TXB ${ }_{2}$, the stable metabolite of TXA $\mathrm{T}_{2}$, and 6-keto $\mathrm{PGF}_{1 \alpha}$, the stable metabolite of prostacyclin, were determined by radioimmunoassay as previously described in detail (5). The protein concentration was determined by the method of Lowry et al. (6). Statistical evaluation of the data was based on the Student's $t$ test for unpaired data.

\section{RESULTS}

$\mathrm{PGE}_{2}$ content per wet weight in the small intestinal mucosa obtained from ovalbumin sensitized and challenged rats was significantly higher than its content in specimens obtained from the control group: $82 \pm 29$ and $51 \pm 23 \mathrm{pg} / \mathrm{mg}$ (mean \pm SD), respectively, $p<0.005$ (Fig. 1). The data remained significant when calculated per mg protein. In the sensitized group consisting of 10 rats it was $691 \pm 310 \mathrm{pg} / \mathrm{mg}$ protein versus $424 \pm 155$ (mean $\pm \mathrm{SD})$ in nine control rats $(p<0.05)$.

6-Keto $\mathrm{PGF}_{1 \alpha}$ content in the small intestinal mucosa obtained from sensitized rats was $2.4 \pm 1.7 \mathrm{pg} / \mathrm{mg}$ wet weight. This value was not significantly different from its content in specimens obtained in the control group, $2.9 \pm 0.7 \mathrm{pg} / \mathrm{mg}$ wet weight (mean $\pm \mathrm{SD}$ ) (Fig. 1). $\mathrm{TXB}_{2}$ in intestinal mucosa specimens obtained from sensitized rats did not differ significantly from the control group $0.8 \pm 0.3$ versus $1.3 \pm 1.0 \mathrm{pg} / \mathrm{mg}$ wet weight (mean $\pm \mathrm{SD}$ ) (Fig. 1).

\section{DISCUSSION}

The gastrointestinal manifestations of food protein hypersensitivity include vomiting, diarrhea, malabsorption, and abdominal pain (7). It is likely that these symptoms have an immunological basis partly explained by an immediate type gastrointestinal allergic reaction to specific food protein. Exogenous PGs, 


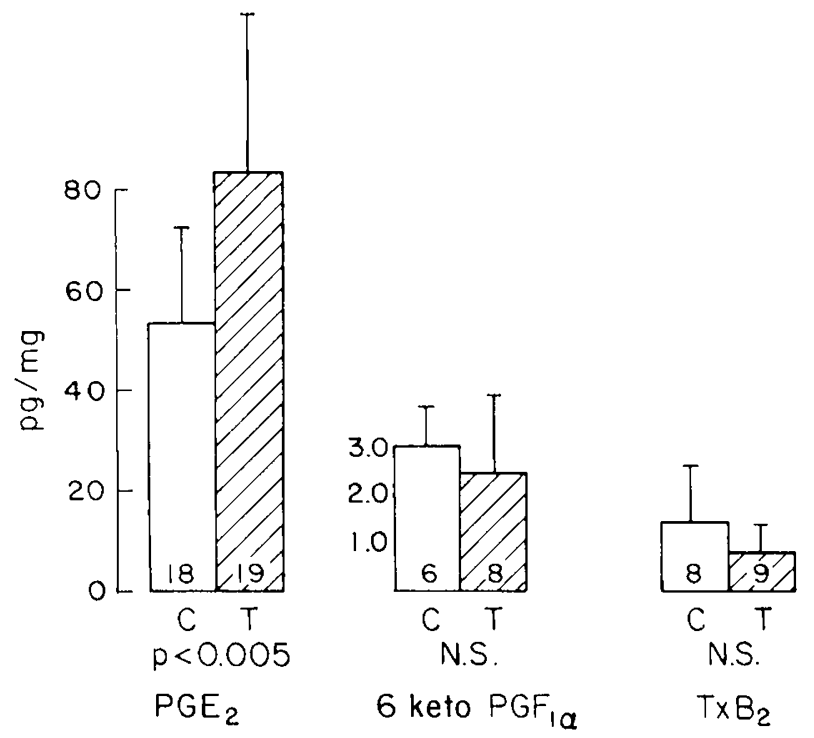

Fig. 1. Prostanoid content of intestinal mucosa in ovalbumin-sensitized and control rats. Values in $\mathrm{pg} / \mathrm{mg}$ wet weight, mean $\pm \mathrm{SD}$. $C$, control; $T$, sensitized group; NS, difference not significant.

in particular $\mathrm{PGE}_{2}$, can affect the gastrointestinal tract by producing diarrhea and modifying intestinal motility. Diarrhea is a recognized adverse effect of PGs administered to pregnant women. Diarrhea has also been observed in volunteers who were treated with $\mathrm{PGE}_{1}(8), \mathrm{PGE}_{2}(9)$, and $\mathrm{PGF}_{2 \kappa}(10)$. Experiments utilizing animal models have demonstrated enteropooling of fluid in response to treatment with $\mathrm{PGE}_{2}(9)$.

The potential role of $P G$ in food allergy has been suggested by Buisseret et al. $(11,12)$. They concluded that PGs $\left(\mathrm{PGE}_{2}\right.$ and $\left.\mathrm{PGF}_{2 \alpha}\right)$ are involved in the mediation of increased intestinal motility and secretion. This hypothesis was based on their observation that in 11 of their 12 patients pretreatment with PG synthetase inhibitor, prior to the food challenge, prevented gastrointestinal as well as the other symptoms. In three of their patients blood and stool PG levels were determined and the changes in their concentrations correlated with the clinical symptoms. Subsequently two other reports on the role of prostanoid in food allergy have been published $(13,14)$. Similarly, Alun Jones et al. (15) have shown a rise in $\mathrm{PGE}_{2}$ in rectal dialysate fluid following challenge by specific allergens in hypersensitive patients.

We have previously used a rat model to study an immediate type allergic response to ovalbumin (2) based on that described by Byars and Ferraresi (3). We believe that in this model the animal suffers from a local intestinal immediate type hypersensitivity for the following reasons. First, the PCA reaction was positive indicating that an immediate type allergy existed. Second, the rapid change in the permeability of the intestine which we measured in our previous experiments (2) was evidence that a local allergic response was taking place. In the present study we demonstrate a significant increase in $\mathrm{PGE}_{2}$ content in the small intestinal mucosa after challenge with egg albumin as compared to unsensitized rats. On the other hand, the content of both 6-keto $\mathrm{PGF}_{1 \times x}$ and $\mathrm{TXB}_{2}$ in the control group was markedly low as compared to the content of $\mathrm{PGE}_{2}$ and no significant change was observed in the contents of 6-keto PGF and $\mathrm{TXB}_{2}$ following challenge with ovalbumin. Other investigators (16) using an identical model have shown that the local intestinal anaphylactic reaction is also accompanied by degranulation of mast cells and release of histamine.

We have also shown an increased intestinal PG content in children suffering from active celiac disease (17). As celiac disease and food protein hypersensitivity share some similar clinical and morphological characteristics it is possible that PG may play a role, at least in part, in the symptomatology of both disorders.

Although the precise cellular origin of PGs is unknown, its biosynthesis is presumed to occur in leukocytes, platelets, endothelial cells through the metabolic pathway of arachidonic acid (18). As the lamina propria of small intestinal mucosa obtained from patients suffering from food-protein hypersensitivity is infiltrated with mononuclear cells, it is conceivable that the increased PG content in the sensitized rats may be attributed to the increased infiltration of these cells in the lamina propria. It is suggested that PGs may contribute to diarrhea in food protein hypersensitivity by stimulating adenylate cyclase activity which increases intracellular cyclic adenosine monophosphate which in turn increases intestinal electrolyte and fluid secretion (19). Moreover $\mathrm{PGE}_{2}$ was demonstrated to decrease jejunal $\mathrm{Na}^{+} \mathrm{K}^{+} \mathrm{ATPase}$ activity, an enzyme which has an important role in the modulation of sodium absorption (20).

Lake et al. (21), however, reported in the rat model that intraduodenal infusion of exogenous $\mathrm{PGE}_{2}$ inhibited the histamine recovery after ovalbumin challenge. It has been shown that $\mathrm{PGE}_{2}$ has cytoprotective properties to chemical injury in the intestinal tract (22). It is thus suggested that PGs may have a protective effect during acute intestinal allergy simultaneously with its known diarrheagenic mechanism. The effect of $\mathrm{PGE}_{2}$ on the immune system may also be relevant. It has been shown that this prostanoid induces nonspecific $\mathrm{T}$ lymphocyte suppressor activity $(23,24)$. These studies relate to peripheral blood lymphocytes, however, and the effect of $\mathrm{PGE}_{2}$ on gut-associated lymphoid tissue remains to be studied.

It is concluded that in the rat model of food hypersensitivity PG content of the intestinal mucosa is elevated. It is therefore suggested that the elevated PGs may contribute, at least in part, to the symptomatology of allergic enteropathy.

Acknowledgment. The authors thank Dr. E. Shohami from the Hebrew University Medical School for her help in PG determination.

\section{REFERENCES}

1. Rask-Madsen J, Bukhave K 1979 Prostaglandins and chronic diarrhea. Scand J Gastroenterol 14(suppl 53):73-78

2. Freier S, Eran M, Goldstein R 1985 The effect of immediate-type gastrointestinal allergic reactions on brush border enzymes and gut morphology in the rat. Pediatr Res 19:456-459

3. Byars N, Ferraresi RW 1976 Intestinal anaphylaxis in the rat as a model of food allergy. Clin Exp Immunol 24:352-356

4. Bauminger S, Zor H, Linder HR 1975 Radioimmunological assay of prostaglandin synthetase activity. Prostaglandins 4:313-324

5. Ligumsky M, Karmeli F, Sharon P, Zor U, Cohen F, Rachmilewitz D 1981 Enhanced thromboxane $A_{2}$ and prostacyclin production by cultured rectal mucosa in ulcerative colitis and its inhibition by steroids and sulfasalazine. Gastrocnterology 81:444-449

6. Lowry OH, Rosenbrough WJ, Farr AL, Randell RJ 1951 Protein measuremen with phenol reagent. J Biol Chem 193:265-275

7. Savilahti E, Kuitunen P, Visakorpi JK 1981 Cow's milk allergy In: Lebenthal $E$ (ed) Textbook of Gastroenterology and Nutrition in Infancy. Raven Press, New York, pp 689-708

8. Matuchansky C, Bernier JJ 1973 Effect of prostaglandin $E_{1}$ on glucose, water, and electrolyte absorption in the human jejunum. Gastrocnterology 64:1111-1118

9. Karim SMM, Adaikan PG 1977 The effect of loperamide on prostaglandin induced diarrhea in rat and man. Prostaglandins 13:321-331

10. Cummings JH, Newman A, Misiewicz JJ 1973 Effect of intravenous prostaglandin $F_{2 x}$ on small intestinal function in man. Nature 243:169-171

11. Buisseret PD, Heinzelmann DI, Youlten IJF, Lessof MH 1979 Prostaglandinsynthesis inhibitors in prophylaxis of food intolerance. Lancet 1:906-908

12. Buisseret PD, Youlten LJ, Heinzelmann D, Lessof MH 1979 Prostaglandin synthetase inhibitors and food intolerance. Monogr Allergy 14:197-202

13. Anderson JB, Lessof MH, Youlten LJF, McDonald-Gibson W, Collicr HOJ 1983 Prostaglandin release in relation to food challenge. In: Coombs RRA (ed) The Second Fisons Food Allergy Workshop Foundation. Medicine Publishing, Oxford, pp 18-20

14. Bellanti JA, Tate SM, Liu WJ, Guillen M, Scanlon RT, Foegh ML, Ramwell PW 1983 The role of histamine and prostaglandins in food allergy. In: Businco L (cd) Advances in Pediatric Allergy. Excerpta Medica, Elsevier Science Publishers, BV Amsterdam, pp 242-250

15. Alun Jones V, McLaughlan P, Shorthouse M, Workman E, Hunter JD 1982 
Food intolerance: a major factor in the pathogenesis of irritable bowel syndrome. Lancet 2:1115-1117

16. Perdue MM, Chung M, Gall DG 1984 Effect of intestinal anaphylaxis on gut function in the rat. Gastroenterology 86:391-397

17. Branski D, Karmeli F, Gross-Kieselstein E, Abrahamov A, Rachmilewitz D 1985 Prostaglandins in small intestinal mucosa of children with celiac disease. J Pediatr Gastroenterol Nutr 3:672-675

18. Zifroni A, Traves AJ, Sachar DB, Rachmilewitz D 1983 Prostanoid synthesis by cultured intestinal epithelial and mononuclear cells in inflammatory bowel disease. Gut 24:659-664

19. Rachmilewitz D 1980 Prostaglandins and diarrhea. Dig Dis Sci 25:897-899

20. Sharon P, Karmeli F, Rachmilewitz D 1984 Effect of prostanoid on human intestinal $\mathrm{Na}^{+}-\mathrm{K}^{+}$-ATPase activity. Isr J Med Sci 20:677-680

21. Lake AM, Kagey-Sobotka A, Jakobowicz T, Lichtenstein LM 1984 Histamine release in acute anaphylactic enteropathy of the rat. J Immunol 133:15291534

22. Robert A 1979 Cytoprotection by prostaglandins. Gastroenterology 77:761767

23. Fischer A, Durandy A, Griscelli C 1981 Role of prostaglandin $E_{2}$ in the induction of nonspecific $T$ lymphocyte suppressor activity. J Immunol 126:1452-1455

24. Kaszubowski PA, Goodwin JS 1982 Monocyte-produced prostaglandin induced $\mathrm{FC} \gamma$ receptor expression on human T cells. Cell Immunol 68:343348 